Note

\section{Preparation of Chiral trans-2,4- Dimethyl-1-cyclohexanones, the Key Intermediates in Cycloheximide Synthesis, Using Microbial Resolution}

\section{Takayuki OrITANI, Hitoshi Kondo and Kyohei Yamashita}

\author{
Department of Agricultural Chemistry, \\ Faculty of Agriculture, \\ Tohoku University, \\ Sendai 980, Japan
}

Received July 31, 1986

Cycloheximide (1), a powerful antimicrobial agent produced by Streptomyces griseus, have been synthesized by an aldol condensation of trans-2,4-dimethyl-1-cyclohexanone (2) with 4-(2-oxoethyl)-2,6-piperidinedione (3) by the authors. ${ }^{1)}$ However, $(+)-2$ that was used for the synthesis of 1 was obtained by the degradation of natural 1, and a practical preparation for chiral trans-2,4dimethyl-1-cycylohexanone (2) was desired. Already, we have demonstrated that microbial hydrolysis of $( \pm)-t-2, t$ 4-dimethyl-r-1-cyclohexyl acetate, followed by the oxidation, gave $(-)-(2 R, 4 R)$-cis-2,4-dimethyl-1-cyclohexanone (6). ${ }^{2)}$ Here, we describe a synthetic method for chiral trans-2,4-dimethyl-1-cyclohexanone (2) by using the microbiological system.

The condensation of 4-methyl-1-cyclohexanone (4) with pyrrolidine gave the enamine $\mathbf{5}$, which was reacted with methyl iodide to form a stereoisomeric mixture of $( \pm)-2,4-$ dimethyl-1-cyclohexanones. The ketones consisted of $86 \%$ of ( \pm )-trans form (2) and $14 \%$ of cis form (6) by gas chromatographic (GLC) analysis with a column of $20 \%$ Hyprose SP-80. Reduction of the ( \pm$)$-ketones 2 and 6 with several reducing reagents afforded a stereoisomeric mixture of $( \pm)$-2,4-dimethyl-1-cyclohexanols, which were analyzed by GLC with a column of 5\% PEG-20M to give the results shown in the table. The reduction of $( \pm)-2$ with $\mathrm{K}$-selectride (potassium tri-sec-butylborohydride) show the highest stereoselectivity to predominantly yield $( \pm)-c$ 2,t-4-dimethyl- $r$-1-cyclohexanol (7b). The ( \pm )-7b fraction was acetylated with acetic anhydride-pyridine to give the ( \pm )-c-2,t-4-dimethyl- $r$-1-cyclohexyl acetate (9) fraction. Asymmetrical hydrolysis ${ }^{2)}$ of the acetate $( \pm)-9$ with a culture broth of Bacillus subtilis var. niger (IFO 3108) afforded $(+)-7 \mathbf{b},[\alpha]_{\mathrm{D}}+30.7^{\circ}(\mathrm{MeOH})$, and the $(-)$-acetate

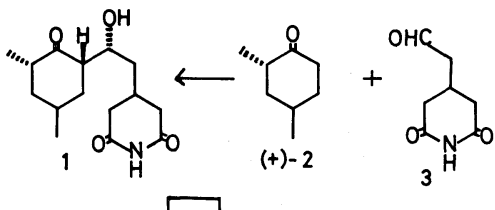

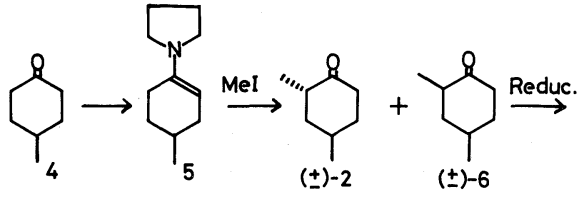

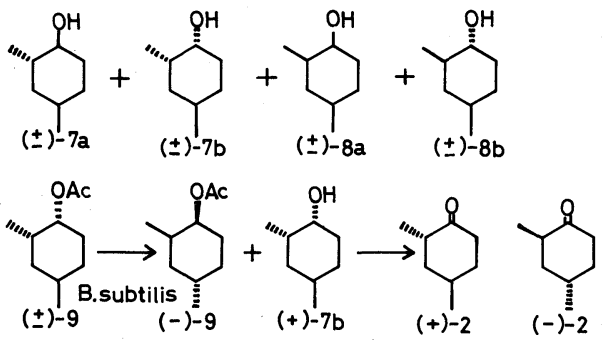

Table I. Reduction Products of ( \pm )-trans-2,4-Dimethyl-1-CycloheXanone (2) Containing ca. 14\% of ( \pm )-cis-2,4-Dimethyl-1-Cyclohexanone (6) with Several Reducing Reagents

\begin{tabular}{|c|c|c|c|c|c|c|}
\hline \multirow{3}{*}{ Reagent } & \multirow{3}{*}{ Solvent } & \multirow{3}{*}{$\begin{array}{c}\text { Reaction } \\
\text { temperature } \\
\left({ }^{\circ} \mathrm{C}\right)\end{array}$} & \multicolumn{4}{|c|}{$\%$ Ratio of the products } \\
\hline & & & \multicolumn{2}{|c|}{$( \pm)$-trans-Alcohols } & \multicolumn{2}{|c|}{$( \pm)$-cis-Alcohols } \\
\hline & & & $( \pm)-7 \mathbf{a}$ & $( \pm)-7 \mathbf{b}$ & $( \pm)-8 \mathbf{a}$ & $( \pm)-\mathbf{8 b}$ \\
\hline $\mathrm{LiAlH}_{4}$ & Ether & 0 & 34 & 47 & 1 & 18 \\
\hline $\mathrm{NaBH}_{4}$ & $\mathrm{MeOH}$ & -5 & 18 & 53 & 10 & 19 \\
\hline $\mathrm{NaBH}_{4}-\mathrm{CeCl}_{3}{ }^{3)}$ & $\mathrm{MeOH}$ & -5 & 10 & 78 & 11 & 1 \\
\hline K-Selectride ${ }^{4)}$ & THF & -30 & 1 & 80 & 19 & - \\
\hline $\mathrm{LiAlH}\left(\mathrm{OCH}_{3}\right)_{3}{ }^{5)}$ & THF & 0 & 12 & 73 & 13 & 2 \\
\hline Redal & THF & -3 & 29 & 51 & 4 & 16 \\
\hline $\begin{array}{l}\left(\left(\mathrm{MeOCH}_{2} \mathrm{CH}_{2} \mathrm{O}\right)_{2} \mathrm{AlH}_{2}\right) \mathrm{Na} \\
\text { Cyclohex }_{2} \mathrm{BH}^{6)}\end{array}$ & THF & $0 \sim 10$ & 11 & 49 & 24 & 16 \\
\hline
\end{tabular}


fraction. Reductive cleavage of the acetate (-)-9 with lithium aluminum hydride gave $(-)-7 \mathbf{b}$. The optical purity of $(-)-7 \mathbf{b}$ and $(+)-7 \mathbf{b}$ was determined by ${ }^{1}$-NMR spectra of their (-)-(S)-MTPA esters to show a $100 \%$ enantiomeric excess (e.e). Oxidation of $(+)-7 \mathbf{b}$ with pyridinium chlorochromate (PCC) gave $(+)-(2 S, 4 R)$-trans-2,4dimethyl-1-cyclohexanone $(2),[\alpha]_{\mathrm{D}}+63.1^{\circ}(\mathrm{EtOH})$, ref.1, $+58.3^{\circ}(\mathrm{EtOH})$. This result means that the $(+)-c, 2, t-4-$ alcohol (7b), that was obtained by the microbial hydrolysis has the $(1 R, 2 S, 4 R)$-configuration. Similarly, (-)-7b was oxidized with PCC to give a $(-)-(2 R, 4 S)$-ketone (2).

\section{EXPERIMENTAL}

1) (+)-2,4-Dimethyl-1-cyclohexanone. A Solution of 4-methylcyclohexanone $(4,46.0 \mathrm{~g}), 53.0 \mathrm{~g}$ of pyrrolidine, and $300 \mathrm{mg}$ of $p$-toluenesulfonic acid in $200 \mathrm{ml}$ of benzene was refluxed for $20 \mathrm{hr}$ with separation of the produced water to give a pyrrolidine enamine $(5,61.0 \mathrm{~g}, 89 \%$ yield), bp $126 \sim 128^{\circ} \mathrm{C}(30 \mathrm{mmHg})$. A mixture of the enamine $(\mathbf{5}$, $61.0 \mathrm{~g}$ ) and $105 \mathrm{~g}$ of methyl iodide in $450 \mathrm{ml}$ of dry benzene was stirred for $20 \mathrm{hr}$ at room temperature. After adding $100 \mathrm{ml}$ of water, the reaction mixture was stirred for $2 \mathrm{hr}$ before $100 \mathrm{ml}$ of $20 \%$ acetic acid was added. Extraction with ether gave a fraction boiling at $85 \sim 90^{\circ} \mathrm{C}(45 \mathrm{mmHg}$, $45.0 \mathrm{~g}$ ) which consisted of $36 \%$ of 6 and $55 \%$ of $( \pm)-2$ by GLC analysis with a $2 \mathrm{~m} \times 3 \mathrm{~mm}$ column of $20 \%$ Hyprose $\mathrm{SP}-80$ (column temp., $130^{\circ} \mathrm{C}$; He flow rate, $24 \mathrm{ml} / \mathrm{min}$ ). The fraction was chromatographed on silica gel, elution with hexane-ether $(9: 1)$ giving $( \pm)$-2,4-dimethyl-1cyclohexanone, bp $70 \sim 75^{\circ} \mathrm{C}(20 \mathrm{mmHg})$, which consisted of $86 \%$ of $( \pm)$-trans-ketone (2) and ca. $14 \%$ of $( \pm)$-cisketone (6). IR $v_{\max }^{\text {film }} \mathrm{cm}^{-1}: 1720,1130,1000$. Anal. Found: C, 76.21;.H, 11.22. Calcd. for $\mathrm{C}_{8} \mathrm{H}_{14} \mathrm{O}: \mathrm{C}, 76.14 ; \mathrm{H}$, $11.18 \%$.

2) Reduction of ( \pm )-2,4-dimethyl-1-cyclohexanone with $K$-selectride. To a stirred solution of $( \pm)-2,4-$ dimethyl-1-cyclohexanone $(1.92 \mathrm{~g})$ in $20 \mathrm{ml}$ of dry THF at $-30^{\circ} \mathrm{C}$ was added $28 \mathrm{ml}$ of a $1 \mathrm{M}$ solution of $\mathrm{K}$-selectride in THF, stirring being continued for $2 \mathrm{hr}$. After adding $30 \mathrm{ml}$ of $10 \% \mathrm{NaOH}$ and $25 \mathrm{ml}$ of $30 \% \mathrm{H}_{2} \mathrm{O}_{2}$, the reaction mixture was stirred for $3 \mathrm{hr}$ at $20^{\circ} \mathrm{C}$ and then poured into water. Extraction with ether gave $1.70 \mathrm{~g}(86 \%$ yield $)$ of ( \pm )-2,4-dimethyl-1-cyclohexanol, bp $91 \sim 100^{\circ} \mathrm{C}$ $(65 \mathrm{mmHg})$, which consisted of $1 \%$ of $7 \mathbf{a}\left(t_{\boldsymbol{R}}: 7.8 \mathrm{~min}\right), 19 \%$ of $8 \mathbf{a}\left(t_{R}: 5.7 \mathrm{~min}\right)$ and $7 \mathbf{b}\left(t_{R}: 8.5 \mathrm{~min}\right)$ by GLC analysis with a $2 \mathrm{~m} \times 3 \mathrm{~mm}$ column of $5 \%$ PEG-20 $\mathrm{M}$ on chromosorb $\mathrm{W}$ (column temp., $90^{\circ} \mathrm{C} ; \mathrm{N}_{2}$ flow rate, $20 \mathrm{ml} / \mathrm{min}$ ). Each stereoisomer of $( \pm)$-2,4-dimethyl-1-cyclohexanonl was identified by co-GLC with authentic specimens. ${ }^{2)}$ The ( \pm )alcohol was chromatographed on silica gel, elution with hexane-ethyl acetate $(9: 1)$ giving pure $( \pm)-c-2, t-4-$ dimethyl- $r$-1-cyclohexanol (7b) as an oil. MS $m / z$ (rel. int.): $128\left(\mathrm{M}^{+}, 4.5\right), 95(100)$. IR $v_{\max }^{\mathrm{film}} \mathrm{cm}^{-1}: 3350,1100,1050$, 1010. ${ }^{13} \mathrm{C}-\mathrm{NMR}\left(\mathrm{CDCl}_{3}, 25 \mathrm{MHz}\right) \delta: 12.5,21.4,25.6,28.9$, $32.3,33.8,39.3,72.4$.
3) ( \pm )-2,4-Dimethyl-1-cyclohexanol, acetate. ( \pm$)-$ 2,4-dimethyl-1-cyclohexanol (1.70 g) was stirred with $2.7 \mathrm{~g}$ of acetic anhydride in $4.2 \mathrm{ml}$ of pyridine for $20 \mathrm{hr}$ at $20^{\circ} \mathrm{C}$ to give $1.80 \mathrm{~g}(80 \%$ yield) of $( \pm)$-2,4-dimethyl-1-cyclohexyl acetate, bp $93 \sim 96^{\circ} \mathrm{C}(30 \mathrm{mmHg})$ IR $v_{\max }^{\mathrm{film}} \mathrm{cm}^{-1}$ : 1740, 1250, 1040 .

4) Microbial hydrolysis of ( \pm )-2,4-dimethyl-1cyclohexyl acetate. Treatment of $3.33 \mathrm{~g}$ of the $( \pm)$-acetate with $500 \mathrm{ml}$ of a culture broth of Bacillus subtilis var. niger IFO $3108^{2)}$ for 2 days at $27^{\circ} \mathrm{C}$, followed by steam distillation, gave an oily mixture, which was chromatographed on alumina to give $1.60 \mathrm{~g}$ of an acetate and $900 \mathrm{mg}$ of an alcohol. Chromatography of the alcohol on silica gel gave $650 \mathrm{mg}$ of $(+)-7 \mathbf{b},[\alpha]_{\mathrm{D}}^{20}+30.7^{\circ}(c=1.39, \mathrm{MeOH}), c a$. $100 \%$ e.e. from ${ }^{1} \mathrm{H}$-NMR of its (-)-MTPA ester. The 3,5dinitrobenzoate had an $\mathrm{mp}$ of $85 \sim 86^{\circ} \mathrm{C}$. The recovered acetate was re-treated with $500 \mathrm{ml}$ of the cultured broth for 1 day and then chromatographed on alumina to give $900 \mathrm{mg}$ of the $(-)$-acetate as an oil, $[\alpha]_{\mathrm{D}}^{20}-11.4^{\circ}(c=1.96$, $\mathrm{MeOH}$ ), which consisted of $76 \%$ of $(-)-(9)$ and $24 \%$ of the 8a-acetate. The $(-)$-acetate $(800 \mathrm{mg})$ was reduced with $180 \mathrm{mg}$ of $\mathrm{LiAlH}_{4}$ in $50 \mathrm{ml}$ of ether for $1.5 \mathrm{hr}$ at $20^{\circ} \mathrm{C}$, followed by silica gel chromatography, and gave (-)-7b, $[\alpha]_{\mathrm{D}}^{20}-30.6^{\circ}(c=0.45, \mathrm{MeOH}), c a .100 \%$ e.e. The $3,5-$ dinitrobenzoate of $(-)-7 \mathbf{b}$ had an $\mathrm{mp}$ of $85 \sim 86^{\circ} \mathrm{C}$. Anal. Found: C, 55.84; $\mathrm{H}, 5.54 ; \mathrm{N}, 8.63$. Calcd. for $\mathrm{C}_{15} \mathrm{H}_{18} \mathrm{O}_{6} \mathrm{~N}_{2}$ : C, $55.89 ; \mathrm{H}, 5.63 ; \mathrm{N}, 8.69 \%$.

5) (-) and (+)-trans-2,4-Dimethyl-1-cyclohexanones (2). To a stirred suspension of $560 \mathrm{mg}$ of pyridinium chlorochromate (PCC) and $43 \mathrm{mg}$ of sodium acetate in $5 \mathrm{ml}$ of dry $\mathrm{CH}_{2} \mathrm{Cl}_{2}$ was added $(+)-7 \mathbf{b}(160 \mathrm{mg})$ in $3 \mathrm{ml}$ of $\mathrm{CH}_{2} \mathrm{Cl}_{2}$, the mixture being stirred for $1.5 \mathrm{hr}$ at $20^{\circ} \mathrm{C}$. Chromatography of the reaction mixture on Florisil gave $140 \mathrm{mg}(88 \%$ yield $)$ of $(+)-2, c a .100 \%$ purity by GLC analysis with $5 \%$ PEG-20M. $[\alpha]_{\mathrm{D}}^{22}+63.1^{\circ}(c=0.63$, EtOH $)$, ORD $(c=0.063, \mathrm{EtOH})_{\mathrm{nm}}:[\phi]_{303}+1,745$ (peak), $[\phi]_{283} 0,[\phi]_{262}$ $-1,514$ (trough). MS $m / z$ (rel. int.): $127\left(\mathbf{M}^{+}+1,6.6\right), 126$ $\left(\mathrm{M}^{+}, 52\right), 82(100)$. Similarly, the oxidation of $(-)-7 \mathbf{b}$ with PCC gave $(-)-2,[\alpha]_{\mathrm{D}}^{21}-63.4^{\circ}(c=0.49, \mathrm{EtOH})$.

\section{REFERENCES}

1) S. Kudo, T. Oritani and K. Yamashita, Agric. Biol. Chem., 48, 2315 (1984).

2) T. Oritani, S. Kudo and K. Yamashita, Agric. Biol. Chem., 46, 757 (1982).

3) J. W. Huffman, R. C. Desai and G. F. Hillenbrand, J. Org. Chem., 49, 982 (1984).

4) H. C. Brown and S. Krishnamurthy, J. Am. Chem. Soc., 94, 7159 (1972).

5) H. C. Brown and H. R. Deck, J. Am. Chem. Soc., 87, 5620 (1965).

6) H. C. Brown and V. Varma, J. Org. Chem., 39, 1631 (1974). 